\title{
The Essay as a Moral Exercise: Montaigne*
}

\author{
JOHN O'NEILL
}

In the Essays ${ }^{1}$ Montaigne achieved a unique conformity between the literary exercises of reading and writing and an order of interiority that enabled him to lend himself to the world and to others without loss, but also without either moral idealism or scepticism. ${ }^{2}$ The literary unity of the Essays, although not as apparent as the integrity of the moral maxims that first figurate them, emerges gradually in the self-portrait of the reader/ writer doubly reflected in Montaigne's own practices and their embodied demands upon the reader's response to the Essays:

La gentille inscription dequoy les Atheniens honorerent la venue de Pompeius en leur ville, se conforme à mon sens:

D'autant es tu Dieu comme

Tu te recognois homme.

C'est une absolue perfection, et comme divine, de sçavoyr jouyr loiallement de son estre. Nous cherchons d'autres conditions, pour n'entendre l'usage des nostres, et sortons hors de nous, pour sçavoir quel il y fait. Si, avons nous beau monter sur des eschasses, car sur des eschasses encores faut-il marcher de nos jambes. Et au plus eslevé throne du monde, si ne sommes assis que sus nostre cul.

(III:xiii, 1096)

If we propose to speak of the Essays as a moral exercise, we do so only in order to follow Montaigne's deconstruction of the ethical portrait, the moral or maxim forced to stand frozen in time like Cato, attracting an admiration deprived of self- inquiry.

What Montaigne exercises in the Essays is himself as a writer, that is to say, he explores his strengths and weaknesses as an essayist rather than as an abstractly moral figure. This exploration begins in the very early and as he himself remarks - rather dependent essays that trade upon the moral maxims and exempla of antiquity. The exemplum condenses a moral deed, posture or maxim into a moment that lays a claim upon universal attention. The exemplum furnishes the mind with places where it may

\footnotetext{
* Paper presented at the Colloquium on Literature and Moral Philosophy, Centre for Comparative Literature. University of Toronto, Victoria College, April 14-17, 1983.
} 
contemplate man's capacity for moral strength or weakness, probity or turpitude. Thus the exemplum punctuates its surrounding text, creating a monumental place that gathers to itself moral reflection with the aim of sending away a more resolute moral agent. As a rhetorical device its danger is that it may lure us into a merely echoing morality that will not stand up in the time and altered circumstances of our own trial.

Montaigne seems to have sensed from the very beginning that the Essays could not be built upon the footings of the exemplum. Indeed, to the extent that they appear only to be a collection of such maxims, the Essays have been pillaged, like the Parthenon, to service those anthologies, garlands and museums of the mind, that display an easy spirituality. If the Essays lacked any stronger principle of composition, then, of course, they would not have withstood the ravages of time, and they would even have been lucky to survive as fragments in our cultural museum. But then we should also have lost the author of the Essays. Or rather, Montaigne would have lost himself through his inability to improvise that form of ethical inquiry that underwrites the Essays as a text that cannot be gathered into a garland of moral maxims, nor into an anthology without an author who will claim it as his own body.

The things that stand the test of time, morally speaking, do so by yielding to time rather than by declaring themselves as eternal archetypes. Such archetypes are indeed nothing but the dead stones of history, always ruined by time, surviving fortuitously or by a bricolage indifferent to their original status. The solidity of the exemplum collapses in virtue of its pretended extra-textuality, its inability to withstand the essayist's amplification of history elsewhere and otherwise brought to similar ends. Montaigne's proliferation of exempla destabilizes them, turning certainty into uncertainty, decisiveness into undecidability. The result is that the textual closure aimed at by the moral maxim or paradigm is subverted in the continuous disclosure of the essayist's triumph over the book of received opinion. A weak intertextuality, trading upon the voices of the past, is replaced by the strong intertextuality of the essay form as an exercise in moral inquiry, judgment and self-appreciation.

Montaigne's method of counterposing to an exemplary moral claim everything that can be said to challenge it rescues ethical argument from both idealism and empiricism. In the course of Montaigne's reading and writing, the space of ethical inquiry is displaced into the essay's exploration of ethical ideals and customary moral behaviour. Between them the writer and the reader articulate the essay in a mode of self-inquiry that progresses through the essayist's ability to so suspend the moral alternatives upon which a given essay turns that none rules the text as a foregone conclusion.

In "Of Cannibals," for example, Montaigne proceeds very gradually to 
subvert the cultural boundary between civilization and barbarism. The revolving distinctions of the essay drive the reader to redistribute his own critical sense of boundaries as a rude practice that only writing/reading the essay can redeem. By combining civilized reportage with the testimony of his own experience, including that of certain plain savages without any motive to embellish their stories, Montaigne reappropriates the boundary between civilization and barbarism as a textual locus. ${ }^{3}$ Thus the essay itself becomes the proper moral space within which the reader can confront the other as himself and himself as other, relativising the very grounds of morality (reason, information, fidelity) to the essayist's ethic. Through the detour of the naked and the familiar, the essayist like a noble savage delivers the unadorned truth of the spoken body, undivided and faithful.

The open form of Montaigne's Essays is the result not of his irresolute nature nor of his failure to embrace logic and closure. It is a shaping instrument of the writer's determination to dwell within the rhythms of his embodied experience. Thus particular essays drift and vary like Montaigne's own moods, occupying him for a longer or shorter period, and often returning upon him, as we see from the triple levels of the text and its innumerable internal revisions. Montaigne's usage of temporal markers and disjunctive adverbs is an especially significant artifact in the essayist's successful subversion of the exemplary text into a self-text. And the places where he succeeds in intertwining his own lived experience with an institutionalized history of morals are similarly marked by subtle shifts from first to third person usage. Thus, having recalled the advice of Epicurus, "Conceal your life," Montaigne himself remarks:

Ces discours là sont infiniment vrais, à mon avis, et raisonnables. Mais nous sommes, je ne sçay comment, doubles en nous mesmes, qui faict que ce que nous croyons, nous ne le croyons pas, et ne nous pouvons deffaire de ce que nous condamnons.

(II:xvi, 603)

The cumulative effect of these distinctive devices is to breed a conversation between Montaigne and his reader in which the text is indifferent to any tendency to mastery or slavery. Rather, the essay solicits a friend, one equal in judgment and ability, less likely to be dominated by words, myths and received opinion for having embraced the essayist.

In the essay form Montaigne discovered a field in which the embodied self could test itself against its written self, as in conversation or in love. ${ }^{4}$ The particular mode in which he devised this contrastive play of selves is to be seen in his typically disjunctive departures from the mould of received sayings, opinions and customs - forcing the text to speak in Montaigne's voice: 


\section{2 / Renaissance and Reformation}

Je propose les fantaisies humaines et miennes, simplement comme humaines fantaisies, et separement considerées, non comme arrestées et reglées parl'ordonnance celeste, incapables de doubte et d'altercation; matiere d'opinion, non matiere de foy; ce que je discours selon moy, non ce que je croy selon Dieu, comme les enfans proposent leurs essais; instruisables, non instruisants; d'une maniere laïque, non clericale, mais très- religieuse tousjours.

(I:1 vi, 308-309)

Such a passage can be repeated time and again. What happens in them is that, in weighing himself against himself, the essayist pits the reader against himself in a game of doubles, as it were. Like a tennis player, the capable reader whom Montaigne required of himself in order to become a writer is simultaneously doubled in any lecteur suffisant of the Essays. Any particular essay, therefore, can be shown to put the reader/writer relation into play over its sense, its language, or its very title. But these are not exercises in any general scepticism. They are rather valorisations of reading and writing, weighed in the scale of a nonchalant and learned ignorance that subverts the anxieties of intertextuality with the consubstantiality of the self-text.

The composition of the self-text involves the steady re-assimilation of the self-absorbing or impersonal voice of the essayist who starts by subordinating himself to a narrative seemingly ruled by received opinion. But each exemplary text soon becomes a pretext whose received authority, once placed in the balance of the essay and weighed in the essayist's own judgment of it, is re-assessed in the opinion of the universal subject Michel de Montaigne:

Les autheurs se communiquent au peuple par quelque marque particuliere et estrangere; moy, le premier, par estre universel, comme Michel de Montaigne, non comme grammairien, ou poëte, ou jurisconsulte. Si le monde se plaint de quoy je parle trop de moy, je me plains de quoy il ne pense seulement pas à soy.

(III:ii, 782-783)

Internal to the composition of the essay, we frequently find that Montaigne succeeds in subverting received opinion by shifting the epistemological question of truth or falsity into the moral question of freedom versus slavery. "Thus the question, "is death something or no-thing (to be feared)?," is transposed into the question, "How are we to free ourselves from the fear of death, how are we to make of it an understanding that is our own?":

Omnem crede diem tibi diluxisse supremum Grata superveniet, quae non sperabitur hora. 
Il est incertain où la mort nous attende, attendons la partout. La premeditation de la mort est premeditation de la liberté. Qui a appris à mourir, il a desapris à servir. La sçavoir mourir nous afranchit de toute subjection et contrainte.

(I:xx, 85)

The effect of this substitution is to reject the tyranny of death and to make of it a friend encountered daily in a premeditated liberty, yet not morbidly.

It is especially in "Du Repentir" that the essay reveals its peculiar fullness as a moral exercise. We ordinarily consider it the task of ethics to define the ideal criteria of a good man whose premeditated form is and ought to be imposed upon the tendency of his senses to scatter and seduce him. Yet Montaigne forswears any such practice of forming man. He argues that, on the contrary, it is in this way that we are mal- and misinformed. Those who submit to such formation, so far from being selfdirected, though less likely to be moved from the outside, remain without internal control, as they know if they at all dare to inspect themselves. By contrast, those like Montaigne, who are apt to lend themselves to the outside, do so without betraying their interior freedom. This reversal of the forms of passage and movement, of stability and being, achieved in so many of the essays, realizes Montaigne's unrepentant claim upon the universal condition of man through his own individual and incorrigible experience of himself:

Je propose une vie basse et sans lustre, c'est tout un. On attache aussi bien toute la philosophie moral à une vie populaire et privée que à une vie de plus riche estoffe; chaque homme porte la forme entiere de l'humaine condition.

(III:ii, 782)

Throughout the Essays Montaigne is engaged against the scholastic presumption of linguistic mastery of truth and being given in a fixed code of rubrics and set definitions. He opposes vehemently the humanist conceit of a transcendental language imposing its rationalist classifications upon a degraded order of experience, despite the fact that this is the level upon which most of us live out the history and geography of our lives:

Nous sommes nés pour agir:

Cum moriar, medium solvar et inter opus.

Je veux qu'on agisse, et qu'on allonge les offices de la vie tant qu'on peut, et que la mort me treuve plantant mes chous, mais nonchalant d'elle, et encore plus de mon jardin imparfait.

(I:xx, 87)

As he says, Montaigne needed a language in which lived experience could find expression without being subordinated or reduced to levels of abstraction and/or formalized usage that bleed the life from it, separating 
the writer's body from his soul in the name of a fancied transcendance of philosophy and literature. For this reason, Montaigne side-steps the rhetorical arts of memory in favour of the paper paths of the Essays, forever side-tracked into those places where the writer finds himself, provided he leaves the royal road of scholastic and set rhetorical reasoning.

Once off the high road of the exemplum and free from the weight of the literary tradition, the poor essayist becomes his own rich resource. Simultaneously, however, he restores his wandering, weak-memoried self with the abundant improvisation of the Essays, thereby revealing the poverty of the literary tradition that might have prevented them. The essayist is then free to shape his formless self, which would otherwise forever escape him in philosophical and literary generalities more deceptive than the phantasies with which he was beseiged before he resolved to become a writer. In other words, so far from losing himself to the world as an essayist, Montaigne discovers in the field of writing the one place where his self can come into the world. But the Essays do not give us Montaigne simply because he wrote about himself in them in all honesty and sincerity and as modestly as he conducted his life outside of them. This would ignore the surplus effect of writing, the pleasure of the text, towards which the writer must also assume a posture whether of modesty or presumption. Thus we find Montaigne re-embedding his literary self in the spoken body, in that bottom nature each of us discovers who listens to his body, especially where the body opens onto language - as in love and poetry. The wild ways of the Essays are not merely diversions and digressions from the via regiae of the book or scholastic treatise. We know that Montaigne prided himself upon a certain poetic dispossession, a fortunate find opened up in the wake of writing to which the essayist trusted himself and his thoughts - not without vanity. It is in this sense that we must regard Montaigne's practice of decentering his text, marginalizing its monumental beginnings, floating everything in search of that supervenient grace achieved through abandoning the fixed architecture of the book for the free form of the essay. Thus the Essays are consciously an element of universal folly, inseparable from the political madness of their day and at once an element of moral stability, enduring the ravages of time like Rome, like the Chateau de Montaigne, and like themselves - through a nonchalant neglect that adds more to their survival than any plan.

If Montaigne concentrates upon himself, it is with a steady attachment to his friend La Boétie, to his family and to his city, and to the voices from the past with whom he conversed in his library. He considered himself a small note in the collective and largely anonymous history of mankind, of which literature and art yield us only a fractured sounding. What is ethical in Montaigne is not his scepticism or his relativism. It is rather his ability to hold life's attachments at a distance in order to consider how it is we are 
nevertheless beholden to everything and everyone around us. Montaigne is not an idle subjectivist, sunk in fantasy or carried away by endless imaginary projects. He knew himself to be among the most variable of spirits, most changeable in his moods, irresolute and without method in the discharge of his affairs. For all this, the Essays are not a series of vile confessions, even though they insist upon self-observation and inquiry. Rather, they 'rebound' from everything that oppresses the mind and the body, whether through the negation of positivity or an affirmation in place of negativity, always ruled, of course, by Montaigne's experience with things and himself. The Essays, then, are Montaigne's happy credo - into which he could pour himself, while simultaneously standing at a Sunday distance from them. They accumulate from a working pleasure in reading and writing and from the prospective joy of finding a reader capable of exercising his own literary competence with the Essays as a continuous bodily inscription. Such pleasure lies outside any literary organization. Hence Montaigne's topics and titles in the Essays serve only as strategies of pleasure, in taking a page from a book or a poem in order to go on writing yet another book or a poem and to continue reading still more books and poems. ${ }^{6}$ And so the Essays find readers who find other readers like friends seeking one another. By word of mouth.

Montaigne employed paradox and a visceral style that awakens the reader's instincts, or his bodily ties to language and community. The effect is that the author and reader enjoy a mutual incarnation pleasured by the text. The Essays shift from the impersonal to the personal voice, from the past to the present, from obiter dicta to the testimony of Montaigne's own eyes, ears and body, and by means of these shifts he heightens the literary company between himself and his reader. By requiring of him his own literary competence, the Essays exercise the reader, and do not simply subordinate him before an exaltation of literary language. Montaigne's style is therefore essential to the liberty of discourse and friendship that excludes tyranny. It requires, too, the solitude represented by his library tower. There he fostered the silence that permits men to choose their words. By contrast, the tyrant - at times played by the literary critic - monopolizes talk, fearing the liberty of discussion, or else he subordinates the arts to his pleasure, denying them any more serious revelation. Hence Montaigne's conceits, paradoxes, humour and self-parody. Hence, also, his insistence upon the publication of his private thoughts, since thoughts without hope of a public cannot be free. For the same reasons, the Essays take their time, walk when they want to, and run when they like, always free to turn to any side that attracts their author, yet never losing themselves for want of their own direction.

Together, Montaigne's love of textuality, i.e., the institution of reading and writing, and his concept of the classical institution of the friendship in 


\section{6 / Renaissance and Reformation}

which the Essays were composed, require that we reject any argument that they are the work of a dependent imagination without any other life, depth or movement than the reflecting mirror or La Boétie and the literary past that surrounded Montaigne. ${ }^{7}$

I am, of course, invoking the moral sense of friendship that is the result of Montaigne's very essay of that notion, as well as how he lived his love for La Boétie. Montaigne's concept of friendship places it above all other moral relationships. It is not an addition to Montaigne's life, nor does it subtract from what he might have owed himself. In friendship, as in essay writing, Montaigne doubled himself. Friendship opened him to himself as the Essays opened him to Michel de Montaigne. In both he gathered himself as the bee gathers its life from the flowers that otherwise give no honey. In reading and writing on his beloved historians and poets he enlarged and gave back to the world the book of himself. For he knew full well that the mirror of Narcissus can only be avoided through the mediation of other minds, in the amplification of discourse and intertextuality. Like Petrarch, Montaigne was faithful to his ancient authors in order rightfully to add himself to them, in a graft of humanity more enduring than the water image of Narcissus.

Thus friendship is a figure of the reader's freedom which the writer knows cannot be constrained by logic, any more than a lover's discourse can constrain the meaning of the love declared through him. ${ }^{8}$ Rather, reader and writer are floated upon one another, like friends and lovers whose talk amplifies their sensory lives, intertwining them with threads they weave about themselves. In such reverberation there can be no false note, though there may be suffering. A false note is struck once only in the music of friendship and love: when mastery or servitude is heard. Then the doubled unity of love and friendship separates or succumbs to tyranny. ${ }^{9}$

The Essays pursue to the very end their own disequilibrium, upsetting the maxims and monuments of morality upon which we are tempted to fixate our lives. Thus by subverting the great lists of history, Montaigne could introduce the history of ordinary everyday living in the great innovation of the Essays as an Ethics. To make this ethical departure, Montaigne had simultaneously to subvert the plenitudes of classical morality in the play of writing and, specifically, in the essayist's quest for freedom from form. Yet the Essays do not simply catch the wind of writing's vanity. On the contrary, there supervenes upon the essayist's practice a discovering awareness of the moral composition of textuality and selfhood in the acquisition of that spoken body which is Montaigne's self-portrait.

The Essays never betray the carnal ambiguity of man's relation to himself, to his reason, his senses, his body and his language. In each case, man must avoid the wilful pursuit of absolute distinctions, of complete certainty and clarity, since these belie his own mixed composition. In exchange for 
foregoing such transcendental excesses, there opened up to the essayist that mundane presence of the literary body to the embodied self which is the one place where the otherwise wholly metaphorical exercise of selfstudy can be practised.

Thus we must locate Montaigne's bodily troubles in writing and reading, upon which he so often remarks, as natural effects of the romance of books. Whereas other critics have seen faults in Montaigne's methods of reading and composition, with the purpose of displaying their own higher morality in these matters, I am arguing that it is precisely in the way that the essayist works that Montaigne gradually established himself as the most serious of all writers, the one most concerned with the bodily regimen of literature and its lively practice. Montaigne never tires of revealing his own incapacities, quirks, and mannerisms of thought and speech. Yet writing was as essential to him as it was to Petrarch or to Rabelais; it was a daily undertaking that he could no more go without than any other bodily function. Montaigne lived the Essays, and waited upon them like the very days of his life for the trail of meaning that life acquires only over its course, and in no other way than at its own expense: in this respect Montaigne may finally be compared with that incomparable artist of the self-portrait, Rembrandt. Convinced of the impossibility of any definitive revelation, the artist and essayist have nevertheless to avoid the traps of narcissism and relativism, of wilful contradiction and ultimate self-defeat. Thus we see in the selfportraits of Rembrandt and in the Essays of Montaigne the gradual dominance of the author's look, mocking, suspicious, candid, proud, humble and caught in the farce. But, with all the strength of natural inquisitiveness and self-scrutiny, these portraits throw back the pain of living, of aging and dying. In both cases, there is a gradual deepening of the expressive potentials of the baroque, away from theatrical dispersion, towards the inner concentration of the soul's body. In a portrait of 1648 , Rembrandt Drawing Himself by the Window, ${ }^{10}$ we have, as in Montaigne's comments upon his own activity as a writer, a subversion of the myth of representation by means of a reflection endlessly reflected upon, unless gathered religiously in each of us. In these two men we are face to face with the mystery of creative work, and with its virtuosity of moving us long after its author has left his hand upon it:

je peins principalement mes cogitations, subject informe, qui ne peut tomber en production ouvragere. A tout peine le puis je coucher en ce corps aërée de la voix.

(II:vi, 359) 


\section{8 / Renaissance and Reformation}

\section{Notes}

1 Oeuvres Complètes de Montaigne. Textes etablis par Albert Thibaudet et Maurice Rat (Paris: Editions Gallimard, 1962). See Appendix for translation of passages cited.

2 Maurce Merleau-Ponty, "Reading Montaigne," pp. 198-210 in his Signs, trans. Richard C. McCleary (Evanston: Northwestern University Press, 1964).

3 Michel de Certeau, “Le lieu de l'autre Montaigne: 'Des Cannabals,'” pp. 187-200 in Le racisme: mythes et sciences, sous la direction de Maurice Olender (Paris: Editions Complexe, 1981).

4 John O'Neill, Essaying Montaigne: A Study of the Renaissance Institution of Writing and Reading (London: Routledge and Kegan Paul, 1982).

5 Lawrence D. Kritzman, Destruction/Découverte: Le fonctionnement de la rhétorique dans les Essais de Montaigne (Lexington: French Forum, Publishers, 1980).

6 Roland Barthes, The Pleasure of the Text, trans. Richard Miller (New York: Hill and Wang, 1975).

7 John O'Neill, “L'essayiste n'est pas un 'malade imaginaire,'” pp. 237-246 in Montaigne et les Essais 1580-1980, actes de Congrès de Bordeaux (Juin 1980), Présentés par Pierre Michel (Paris-Genève: Champion-Slatkine, 1983).

8 Roland Barthes, $A$ Lover's Discourse, Fragments. Translated by Richard Howard (New York: Hill and Wang, 1978).

9 John O'Neill, "Power and the Splitting (Spaltung) of Language," New Literary History, 14 (1983), 695-710.

10 Jean Paris, Tel qu'en lui-même il se voit, 'Rembrandt' (Paris: Librairie Hachette, 1965), p. 122. 